creditor. Whichever solution will finally be chosen, care ought to be taken that no revival judgment be enforced unless the judgment debtor was sought to be informed of the revival proceedings in a manner reasonably calculated to notify him of the pending proceedings.

\title{
THE SEARCH FOR "REASON AND EXPERIENCE" UNDER THE FUNK DOCTRINE
}

"[A] wife cannot be produced either against or for her husband, 'quia sunt duae animae in carne una." " So spoke Coke of the common-law principle. "[T]here is none now so poor as to do it reverence." So spoke Judge Clark of the same principle in United States v. Walker. ${ }^{2}$ But his was the dissent, and the majority opinion by Judge Learned Hand upheld one-half the principle, though not the Latin, so that it was reversible error to allow a wife to testify against her husband.

Walker was convicted of transporting in interstate commerce money "taken feloniously by fraud with intent to steal or purloin." 3 After having gone through the form of marrying the complainant, one Mary Asche, when he was already married to another, he obtained two large sums of money from her and absconded to New York. On previous occasions he had victimized his wife and another woman in much the same manner, and the trial court admitted the testimony of these two ladies on the issue of Walker's fraudulent intent in the crime charged. In reversing the district court, Judge Hand retained the common-law rule that the husband has a privilege to prevent his wife from testifying against him. ${ }^{4}$ Hand felt that before this rule be overthrown, the court must "await the choice of Congress between the conflicting interests involved, or such an overwhelming general acceptance by the states of abolition of the privilege, as induced the Supreme Court to action in Funk v. United States." Judge Clark, dissenting vigorously, called for the abolition of the privilege as accomplished by another federal court of appeals. ${ }^{6}$ Even more emphatically did he denounce the majority's refusal to broaden the common-law doctrine of "necessity," a doctrine which permitted a wife who had suffered personal wrongs at her husband's hands to testify against him. Clark saw reason as requiring the extension of this exception to the case where the wife, though not the actual complainant, is yet desirous of testifying to a "Chinese copy" of the offense charged. He felt the majority had not faced modern realities in the spirit invoked in the Funk case

$\therefore$ Co. Litt. ${ }^{*} 6 \mathrm{~b}$.

${ }^{2}{ }_{7} 6$ F. 2 d 564, 569 (C.A. 2d, I949), cert. den. 338 U.S. 89 I (I949).

348 Stat. 794 (I934) and 53 Stat. II78 (r939), I8 U.S.C.A. $\$ 4 \mathrm{r}_{5}$ (Supp. r948), revised 62 Stat. 862 (1948), I8 U.S.C.A. \& 2314 (1948).

48 Wigmore, Evidence $\$ \$ 2227-28$ (1940).

5 United States v. Walker, note 2 supra, at 568 .

6 Yoder v. United States, 80 F. 2d 665 (C.C.A. Ioth, I935). 
and embodied as a mandate in Rule 26 of the Federal Rules of Criminal Procedure. ${ }^{7}$

Prior to the Walker case, other federal circuit courts of appeal had disagreed on the same issue. The tenth circuit had admitted the testimony of a wife called as a prosecution witness against her husband. ${ }^{8}$ The third and sixth circuits had concluded that one spouse could not so testify against the other. 9 The disagreement among the federal courts finds its roots in the well-known case of Funk v. United States. ${ }^{x}$ That case purported to lay down a fresh rule as to the admissibility of evidence in federal criminal cases. ${ }^{\text {II }}$

When the Supreme Court decided the Funk case in I933 it resolved a longstanding conflict as to the rules governing the admissibility of evidence in federal criminal cases. On the one hand lay a line of decisions stemming from United States v. Reid, ${ }^{2}$ holding that the admissibility of evidence in federal criminal cases was governed by the law of the state as it existed at the time of the Judiciary Act of $I 789$ or at the date of the state's admission to the Union. ${ }^{{ }^{3}}$ On the other hand this line had been broken by the decisions in Benson v. United States $^{\mathrm{T}_{4}}$ and Rosen $v$. United States ${ }^{\mathrm{T}_{5}}$ which had looked to "general authority and sound reason" and "legislation and the very great weight of judicial authority." The result was confusion among the federal courts. ${ }^{x 6}$ But the Funk case faced the issue squarely, decided upon the liberal view and sloughed off the age-incrusted Reid doctrine. With the specific issue before it of the competency of a wife to testify for her husband, the Court, to be sure, found the common law controlling. However, "the common law is not immutable but flexible, and by its own principles adapts itself to varying conditions." ${ }^{17}$ The Court was not, in the face of greatly changed conditions, still chained to the ancient formulae. But the new criteria laid down were anything but precise, for the Funk decision required the federal courts to look simultaneously in three directions: to the principles of the

${ }^{7} 54$ Stat. 688 (I940), I8 U.S.C.A. following $\$ 687$ (I948).

8 Yoder v. United States, note 6 supra.

9 Paul v. United States, 79 F. 2d 56I (C.C.A. 3d, I935); Brunner v. United States, 668 F. $2 \mathrm{~d} 28 \mathrm{r}$ (C.C.A. 6th, $\mathrm{I948}$ ).

${ }^{10} 290$ U.S. 37 I (I933). II Tbid., at 380-86.

${ }^{12} x_{2}$ How. (U.S.) 360 ( $185 I$ ).

${ }_{3}$ Logan v. United States, I44 U.S. 263 (I892); Hendrix v. United States, 219 U.S. 79 (I9II); Jin Fuey Moy v. United States, 254 U.S. I89 (I920); Olmstead v. United States, 277 U.S. 438 (I928).

${ }^{24} 146$ U.S. 325 (I892).

15245 U.S. 467 (Igr8).

${ }^{16}$ The conflicting lower court decisions are classified in Sweeney, Federal or State Rules of Evidence in Federal Courts? 27 Ill. L. Rev. 394 (I932). For analysis of the decisions leading to the Funk case, see Leach, State Law of Evidence in the Federal Courts, 43 Harv. L. Rev. 554 (r930).

${ }^{17}$ Funk v. United States, 29o U.S. 37x, 383 (1933). 
common law (though it was by no means clear that there was a federal common law), to the great weight of state authority (which had long since decreed the abolition of the marital privilege), and to reason itself. As Justice Stone phrased it in Wolfle v. United States: "IT] "[Te competence of witnesses in criminal trials in the federal courts ... [is] governed by common law principles as interpreted and applied by the federal courts in the light of reason and experience."

In I940, the Funk rule was codified in Rule 26 of the Federal Rules of Criminal Procedure: "The admissibility of evidence and the competency and privileges of witnesses shall be governed, except where an act of Congress or these rules otherwise provide, by the principles of the common law as they may be interpreted by the courts of the United States in the light of reason and experience." The Notes of Advisory Committee on Rules assert: "This rule contemplates the development of a uniform body of rules of evidence to be applicable in trials of criminal cases in the federal courts. ... The rule does not fetter the applicable law of evidence to that originally existing at common law. It is contemplated that the law may be modified and adjusted from time to time by judicial decisions." $2 x$

While the Funk court itself had emphasized only liberation from the ancient rules of evidence, it is clear that the draftsmen of Rule 26 saw uniformity as an equally important objective. The victory over adherence to antiquated state law ${ }^{22}$ was to be utilized as a mandate for a modern judge-made "federal law" of evidence. This view of the Funk decision was shared by contemporary commentators, ${ }^{23}$ although many of them displayed a prophetic skepticism as to the possibilities of success in view of the vague criteria laid down in the case. In any event, the lower courts found an invitation to create such a federal law of evidence ${ }^{24}$ and Rule 26 followed suit. If modernization and uniformity can be taken

${ }^{28} 29$ I U.S. 7, 12 (1934).

19 For the other realistic alternative-conformity to current state law-see, Leach, op. cit. supra note I6, at 583-85. For notes approving the Funk decision, see 20 Va. L. Rev. 590 (I934); I4 B.U.L. Rev. I78 (1934); 33 Mich. L. Rev. 3 O7 (I934); 23 Ky. L. J. I9o (1934); 82 U. of Pa. L. Rev. 406 (1934). For expressions of doubt see notes cited infra note 23.

${ }^{20} 54$ Stat. 688 (I940), r8 U.S.C.A. following $\$ 687$ (I948).

$2 x$ Ibid., at 250 (Supp. I948).

23 Under the Reid doctrine the federal courts had been bound by the common law of the state wherein they sat as it existed in $I 789$. They could not look to statutes enacted subsequently. Progressive as their states became, they were compelled to administer the law of evidence as dictated by the rules of 1789 . Under the Benson and Rosen cases, a liberalized alternative was presented, but until the Funk case the lower courts were only confused. See Leach, op. cit. supra note r6.

${ }^{23}$ Howard, Evidence in Federal Criminal Trials, 5 I Yale L.J. $76_{3}$ (I942); Rules of Evidence in Federal Criminal Trials, 47 Harv. L. Rev. 853 (1934). See also, Changes in the Federal Rules of Evidence in Criminal Trials, 43 Yale L.J. 849 (1934); Admissibility of Evidence in Criminal Trials in Federal Courts, 22 Calif. L. Rev. 448 (r934). Compare Justice Frankfurter's reference to the "federal rule," quoted note 46 infra.

24 Cases cited note 25 infra. 
to constitute the design of the Funk doctrine, an appraisal of the subsequent federal cases reveals that these objectives have not been realized.

The Funk doctrine asserts that common-law principles as interpreted in the light of "reason and experience" are to govern. At the outset the difficulties in administering this rule seem apparent. Common-law principles do not exist in vacuo. Where, then, are the federal courts to seek them? Their own prior decisions can be of little assistance, for, as a result of the Reid case, these presumably house only the $\mathrm{I}_{7} 89$ common law. When courts, desirous of abrogating their prior decisions as to evidential matters, turn to "reason and experience" for their guide the problem is posed-what is it that constitutes "reason and experience"?

The cases dealing with the marital privilege-the privilege of the party spouse to exclude the testimony of the other spouse-most clearly disclose the manner in which federal judges have attempted to cope with the Funk doctrine. ${ }^{25}$ For it is only the cases dealing with this evidentiary rule that show a sufficient development to reward detailed examination.

Yoder v. United States had involved a prosecution for transporting a female in interstate commerce for immoral purposes. In a strong dictum, the court expressly abolished the marital privilege..$^{26}$ It found the exclusionary rule out of line with the Funk case and the "clear and decided trend towards removing the bar of incompetency." In Paul v. United States, ${ }^{27}$ a prosecution for forgery of a government check, the court found error in the admission of a husband's testimony against his wife. The common-law rules that one spouse could not testify for or against the other, although relaxed by the Funk case to allow testimony for, had not been so relaxed as to. permit testimony against the other spouse. In Brunner v. United States, ${ }^{28}$ a prosecution for removing currency from the mails, the court found reversible error in permitting the wife to testify for the prosecution against her husband. Faced with the conflicting decisions of the Paul and Yoder cases; with the express reservation in the Funk case-"her competency to testify against him is not involved"; with the Funk doctrine as embodied in Rule 26; and with the Supreme Court decision in Graves v. United

2s Other cases employing the Funk doctrine are: Ledford v. United States, I55 F. 2d 574

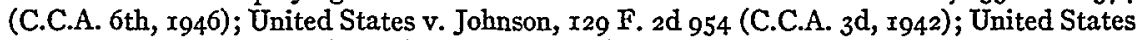
v. Montgomery, I26 F. 2d 15x (C.C.A. 3d, r94I); United States v. Gonella, I03 F. 2d 123 (C.C.A. 3d, 1939); Ex parte United States, Ior F. 2d 870 (C.C.A. 7 th, I939); Smith v. United States, ro6 F. 2d 726 (C.C.A. 4th, x939); Coile v. United States, roo F. 2 d 806 (C.C.A. 5th, I939); Lucks v. United States, roo F. 2d 908 (C.C.A. 5th, I939); Valli v. United States, 94 F. 2d 687 (C.C.A. Ist, I938); United States v. Manton, I07 F. 2d 834 (C.C.A. 2d, 1938); Latgis v. United States, 97 F. 2d 588 (C.C.A. 4th, I938); Melaragno v. United States, 88 F. 2d 264 (C.C.A. 3d, I937); United States v. Williams, 55 F. Supp. 375 (Minn., I944); United States v. McGlone, I9 F. Supp. 285 (Pa., I937).

${ }^{26}$ Yoder v. United States, 80 F. 2 d 665 (C.C.A. Ioth, x935). In fact, husband and wife were divorced and the privilege thus rendered inoperative by common-law doctrine. See 8 Wigmore $\$ 2237$ (1940). But the court chose not to rely on this ground, clearly indicating it would have reached the same result had divorce never taken place.

${ }^{27} 79$ F. $2 d$ 56r (C.C.A. 3 d, ${ }_{935}$ ). ${ }^{28}$ I 68 F. 2 d 28 r (C.C.A. 6th, 1948$)$. 
States, ${ }^{29}$ decided forty years before the Funk case and holding a wife incompetent as a witness against her husband; the court felt compelled to accept the opinion of the Supreme Court in the Graves case as the correct criterion of the law. It would await a decision "in the light of reason and experience" by that Court that it is desirable to remove the privilege before it would so hold.

But it is in the Walker case that the difficulties in applying the Funk doctrine are most vividly disclosed. Judge Hand would abolish the privilege in the federal courts only after such abolition has been generally accepted by the various states. The Funk case and its acknowledged precedent, the Rosen case, had overturned the old rule only where it had been already condemned by the great weight of state authority. ${ }^{30}$ Looking more to what the Funk court did than to what it said, the guide became not so much the "reason" which could be summoned to the defense or attack of the privilege, but rather that "reason" which would be demonstrated by a consensus of state action in overthrowing the privilege. With only a minority having abandoned the marital privilege, ${ }^{3 \mathrm{r}}$ it was to remain part of the federal law of criminal evidence.

Judge Clark, on the other hand, found in the Funk doctrine the power to "discover anew a rational rule." The "reason and experience" of a veteran judge and thoughtful critics would look to the policy behind the privilege and that behind its exception of "necessity." The arguments against retention of the privilege are well-known: the mere fact that it is applied to the husband-wife relationship, yet not to the other intimate family relationships, indicates an illogical basis; ${ }^{32}$ and the doing of justice through admission of relevant testimony must outweigh any feelings of "natural repugnance" which may be felt when one spouse testifies against the other. ${ }^{33}$. Perhaps the most cogent reason of all is that the privilege in no way serves to protect marital harmony, inasmuch as it is ordinarily invoked only when one spouse desires to testify against the other, and where, presumably, the marriage is already on the rocks. ${ }^{34}$ This consideration argues as well for the extension of the exception of "necessity," 35 and, perhaps because the privilege does find some support in logic ${ }^{36}$ and may have consider-

${ }^{29}$ I5० U.S. II8 (1893).

${ }^{30}$ See 2 Wigmore, Evidence $\$ \S 602,524,488$ (I940).

${ }^{37}$ See 8 Wigmore, Evidence $\S 2245$ (x940); 2 Wigmore, Evidence $\$ 488$ (1940). The privilege is apparently abolished in eight states.

${ }^{32}$ Hutchins and Slesinger, Some Observations on the Law of Evidence: Family Relations, I3 Minn. L. Rev. 675, 677 (r929).

338 Wigmore, Evidence $\$ 2228$ (1940).

$34 \mathrm{Ibid}$. See A.L.I. Model Code of Evidence, Rules 214, 215, and 344 (r942).

358 Wigmore, Evidence § 2239 (1940).

${ }^{36}$ There is always possibility of reconciliation which might be lost if hostile testimony is admitted. Hand's argument is that courts are incapable of inquiring into the existing strength of the marital relationship-that divorce is the only test. Clark contends that the existing condition of the relationship is easily discerned by the trial judge. United States v. Walker, note 2 supra, at 568,569 . See also Hutchins and Slesinger, op. cit. supra note 32 , at $68_{3}-86$, indicating the large measure of ambivalence that exists between spouses. 
able public acceptance, ${ }^{37}$ Judge Clark devoted most of his opinion to advocating an extension of the "necessity" exception to the case where the wife, though not the prosecutrix, wishes to appear as a corroborative witness..$^{8}$ But it is clear that, rather than merely limiting the privilege, he would have preferred to use - the Funk rule as a means of abolishing it altogether.

It is on grounds such as these that Clark's dissent rests. The argument obtains no support in traditional application of the common-law rules; it is unsupported by precedent; it is an argument which may be tolerated only as an interpretation of common-law principles in the light of "reason and experience," and was as such, offered as an application of the Funk doctrine.

The opinions of Judges Clark and Hand represent the polar views as to the

37 The fact that the privilege has survived through centuries suggests that all reason is not against it. The reason behind it is moral, and morals frequently are only dimly seen. Wigmore discerned it when he found a "natural repugnance in all fair-minded men," but he dismissed it too easily as "sentiment." Morality, in truth, resides not in the general but in the specific proposition. The true moral rule is not "Thou shall not kill" but "Thou shall not killexcept in self defense, in war, etc." So morality says: "The wrong-doer shall be punishedexcept by means of his wife." This public "dispensing" of justice is by no means rare; it finds similar expression in the distaste felt by the public towards the squealer and the stool pigeon. When it is realized that the trust reposed in the marriage relation is elsewhere unequaled, it is seen why our morals are intolerant of a wife's testimony against her husband. Betrayal of this trust (and it is small matter whether broken by testimony as to "confidential communications" or noncommunicative acts learned of by virtue of the relation) is indeed morally reprehensible. The law too, is a moral force, and what it sanctions it raises in value. The institution of marriage is most basic to society. By privileging its essential trust, the law approves the marriage relation. And it is not true that the law of evidence has no existence outside of the courts (Hutchins and Slesinger, op. cit. supra note $3^{2}$ ), for of all rules, at least this one-that a woman may not testify against her husband-is part of the public's understanding. The ancient lament of the luckless Lord Audley yet rings in the ear of man: "Woe to that man, whose Wife should be a Witness against him!" Lord Audley's Trial, 3 How. St. Tr. 40r, 415 $(I 63 I)$.

${ }^{38}$ Clark notes that in neither the Yoder nor Brunner cases was the wife the complaining witness, yet the point was never pressed. Walker v. United States, note 2 supra, at $569 \mathrm{n}$. 2. But it is also noteworthy that in neither case had the wife been the victim of harm at her husband's hands. For this reason then, there would be no attempt to bring in the wife's testimony under the exception of necessity. The concept of "necessity" indeed proves troublesome when brought into focus. If it is to arise whenever deemed necessary to obtain sufficient evidence for the prosecution of the case, then clearly it may destroy the marital privilege whether the wife is the complainant or merely a corroborative witness. Such wide application is desired by Clark as an alternative to outright revocation. In fact, such an extension would appear to be a substantial revocation of the privilege. Wigmore, op. cit. supra note 33, suggests an interpretation of the exception from which Clark also argues: the exception arises where the reason for the privilege ceases. That is, the common law found the exception of necessity in cases of personal injuries by the husband upon the wife-where marital harmony must have dissolved. There being no reason for the privilege, an exception was invoked. This analysis, though logical in Wigmore's view of the privilege, ignores the natural meaning of the word "necessity" as well as its apparent common-law meaning. Wigmore finds the necessity to be "that necessity to avoid that extreme injustice to the excluded spouse which would ensue upon an undeviating enforcement of the rule." On this view of the exception, it would seem that where the wife is not the complainant there can be no extreme injustice to her. It is assumed that she has a remedy in her own right for any harm caused her by her husband through invocation of the exception of "necessity." The exception is discussed in Shores v. United States, I74 F. 2d 838, 839 (C.A. 8th, x949). 
sources from which the "reason and experience" of the Funk doctrine are to be drawn. But in addition there are other sources to which the federal courts could look in their efforts to comply with the Funk directive. Thus they might rely on the modernized law of the state wherein they sit. 39 But perhaps because of the liberation from the law of the home state afforded by the Funk case itself, the courts have been reluctant thus to restrict themselves..$^{40}$ Another limiting view might be to look only to federal decisions. In this connection, the Wolfle court said: "[C]ommon law principles as interpreted and applied by the federal courts in the light of reason and experience" were to govern. ${ }^{\mathrm{I}}$ There are indications here that a federal law was envisioned with the federal courts looking to each other for the modern rule. But since the body of federal decisions contain only the old common-law rules, the courts are forced to look elsewhere if they are to establish a modern rule..$^{2}$ With the impracticality of these alternatives apparent, the realistic choice can only be between Clark's liberal view and Hand's restrictive one. From the first will spring arguments fed by logic, text-writers, minority jurisdictions, and (what may contain all these) the individual court's own reason and experience; from the second will grow arguments resting on the collective "reason and experience" of the states.

It is clear that Judge Clark is ready to sacrifice the objectives of uniformity and certainty to the end that modernization may be achieved. Whether uniformity and certainty in the rules of evidence are goals of prime importance is an open question. ${ }^{43}$ It is at least as doubtful whether rapid modernization is worthwhile if it entails an extended period of uncertainty and confusion. In any event, the expressed reluctance of the Supreme Court to grant certiorari on evi-

39 In practice, such a method might well produce modernization although uniformity among the circuits would be inconceivable. Prior to the Funk decision, Leach advocated conformity to current state law. See Leach, op. cit. supra note 16 .

${ }^{40}$ See United States v. Montgomery, I26 F. 2 d I5I (C.C.A. 3 d, I94I); Coile v. United States, 100 F. 2d 806 (C.C.A. 5th, 1939); Lucks v. United States, roo F. 2 d 908 (C.C.A. 5th, r939); United States v. Williams, 55 F. Supp. 375 (Minn., I944); Valli v. United States, 94 F. 2d 687 (C.C.A. Ist, 1938).

${ }^{4}$ Wolfle v. United States, 291 U.S. 7, I2 (x934).

${ }_{43}$ See Melaragno v. United States, 88 F. 2 d 264 (C.C.A. 3 d, x937); United States v. Gonella I03 F. $2 d$ I23 (C.C.A. 3d, I939); Smith v. United States, I06 F. 2d 726 (C.C.A. 4th, I939); Ex Parte United States, ror F. 2d 87o (C.C.A. 7th, I939).

43 While the arguments on behalf of the marital privilege assume the contrary, it may be forcefully argued that individuals do not govern their conduct by evidentiary rules. And it may be contended that once the court of appeals for a particular circuit has decided an evidence question, sufficient certainty among the lower courts of that circuit will result. On the other hand, it appears desirable to afford, on the same state of facts, conviction or acquittal in one circuit as well as another. See Holtzoff, Reform of Federal Criminal Procedure, I2 Geo. Wash. L. Rev. Ix9 (I944); Holtzoff, Codification of Federal Criminal Procedure, 4 F.R.D. 275, 282 (I945); Vanderbilt, New Rules of Federal Criminal Procedure, 29 A.B.A.J. 376 (r943). Moreover, a uniform body of federal law may well serve to stimulate uniformity among the several states. The process of modernization inevitably involves frequent change in the rules of law, but all changes are not necessarily improvements. 
dentiary questions ${ }^{44}$ might appear to have all but destroyed the hope of substantial uniformity in the federal courts unless the circuits should voluntarily adopt Hand's view of the Funk mandate.

Under Fand's interpretation of the Funk case, the movement towards modernization would admittedly be slowed. And one may question whether the criterion of the general abolition by the states of the privilege in fact offers a more precise directive than do "reason and experience." Ambiguity resides in "general abolition." Courts will differ as to whether an overwhelming majority of the states, a bare majority of the states, or a minority group composed of the most important or most populous states, will be sufficient. And for some evidentiary questions, e.g., res gestae, it may even be difficult to determine what the rule is in any particular state. Finally one may doubt whether a federal court, faced with the question, will completely ignore the action that has been taken by the other federal circuits. 45

Whatever potential difficulties it may contain, Judge Hand's proffered interpretation of the Funk doctrine undeniably does confine to a relatively narrow area the sources which may be consulted in the search for "reason and experience." If this approach were generally adopted in the federal courts, it is unlikely that the sharp conflict among the circuits, exemplified by the status of the marital privilege, would long continue to exist. There can be no rule better designed to generate difference than one authorizing courts to rely on their own reason and experience.

While a modern uniform federal law of criminal evidence has come to be accepted as the goal of the Funk doctrine, it is only too apparent that this goal will not easily be reached..$^{6}$ As the lower courts await their "federal law," they are at the same time placing it beyond their reach. The Supreme Court itself, in deciding an evidentiary problem, has indicated grave reluctance to place modernization above considerations of certainty. In Michelson v. United States ${ }^{47}$ that Court said: "[T]he present suggestion is that we adopt for all federal courts a new rule as to cross-examination about prior arrest, adhered to by the courts of only one state and rejected elsewhere. The confusion and error it would engender would seem too heavy a price to pay for an almost imperceptible logical improvement, if any, in a system which is justified, if at all, by accumulated judicial experience rather than abstract logic." The common-law rule may justifiably live on, though "reason" insists it should not.

44 Michelson v. United States, 335 U.S. $469,486-87$ (I948).

45 Hand himself appears to consider other federal decisions. See United States v. Walker, note 2 supra, at 568 .

${ }_{4}^{6}$ See Michelson v. United States, note 44 supra. It should be further noted that in Griffin v. United States, 336 U.S. 704, 7 I4 (1948), Justice Frankfurter, in explaining the distinction between the law applicable in federal courts generally and that applicable in the District of Columbia, asserted: "The federal courts have held that one spouse cannot testify against the other unless the defendant spouse waives the privilege. ... Since this court in the Funk case left open the question whether the rule should be changed, . . it presumably is still the 'federal rule' for the lower courts."

${ }^{47} 335$ U.S. $469,486-87$ (1948). 